\title{
Credibility Assessments as 'Normative Leakage': Asylum Applications, Gender and Class
}

\author{
Hanna Wikström ${ }^{1,2, *}$ and Thomas Johansson ${ }^{3}$ \\ ${ }^{1}$ Department of Social Work, University of Gothenburg, Box 720, 40530 Gothenburg, Sweden; \\ E-Mail: hanna.wikstrom@socwork.gu.se; Tel.: +46 703639553; Fax: +46 317865754 \\ ${ }^{2}$ Faculty of Law, University of Uppsala, Box 512, 75120 Uppsala, Sweden; E-Mail: hanna.wikstrom@jur.uu.se \\ ${ }^{3}$ Department of Pedagogy, Learning and Communication, University of Gothenburg, Box 300, \\ 40530 Gothenburg, Sweden; E-Mail: thomas.johansson@ped.gu.se \\ * Corresponding author
}

Submitted: 5 June 2013 | In revised form: 4 September | Accepted: 10 October 2013 | Published: 25 October 2013

\begin{abstract}
Based on the assumption that credibility assessments function as 'normative leakage' within the asylum process, we analyse how narratives of gender and class are articulated, rendered meaningful, or silenced in credibility assessments. Two cases concerning male applicants are selected in order to illustrate these processes. In relation to the existing concepts of internal/external credibility, we wish to introduce the concept of social credibility, which focuses on how the assessors read different socio-cultural narratives. While previous research has shown that the postcolonial will to protect women favours women as victims of patriarchal cultures, we wish to point out the continuity of this line of argumentation in relation to male and female applicants by adopting a theoretical generalization: male applicants instead become situated at the other end of the spectrum of postcolonial notions of modernity as non-victims, victims of other circumstances or perpetrators. We argue that these processes are accentuated in relation to credibility assessments. In order to prevent processes of social exclusion and to enhance inclusive practice, authorities need to acknowledge the 'normative leakage' associated with the assessment process.
\end{abstract}

Keywords: asylum process; case study; class; credibility assessments; gender; norms; postcolonial 


\section{Introduction}

According to the Swedish Alien Act ([1], Ch. 4:1§, emphasis added), a refugee is a person who:

Resides outside the country of which the foreigner is a citizen, because he or she experiences wellfounded fear of persecution due to race, nationality, religious or political beliefs or due to gender, sexual orientation or other membership of a particular social group, and is unable...to avail him- or herself of this country's protection.

The asylum process is often described as fairly objective, but there are considerable degrees of uncertainty and complexity $[2,3]$. Differentiation between just and unjust claims and grounds for asylum rests upon assessment of the applicant's ability to demonstrate the right kind of experiences and future fears. Because many of the conditions related to asylum cannot be proven, the credibility of the claims made is at the core of the assessments.

Our point of departure in the present article is that credibility assessments function as room for 'normative leakage' within the asylum process $[4,5]$. The metaphor 'normative leakage' refers to the use of what Spijkerboer ([4], see also [6]) calls 'normative standards' in the assessment of credibility, in our case standards based on gender and class. We argue that normative standards are frequently used but not acknowledged as such in the assessment process, and that this is what constitutes the 'normative leakage'. In the asylum process, gender usually refers to women and is a relevant topic because a great deal of criticism has been directed at authorities' ability to deal with gender as a social category. The main criticism concerns the fact that asylum legislation is not thought to cover the specific vulnerability of women, e.g., cases of domestic abuse and/or difficulty making a living or earning respect in society [79]. It is argued that persecution tends to be equated with state persecution $[10,11]$, and the refugee with a man who has pursued active political actions in public $[4,5,10,12,13]$. These underlying assumptions or discourses tend to negate the statements of women, in that persecution targeting women is often linked to non-state rather than 'state actors' $[6,8,9,11,12,14]$. It is acknowledged that while forcibly displaced men face protection problems, women are exposed to particular protection problems related to their gender, as well as to their cultural and socio-economic position, as shown above $[8,9]$. In our reading, this implies that gender and socio-economic position/social class are (1) important categories within the asylum process and (2) not acknowledged in the research in relation to men. Oxford [14] calls this phenomenon gender synonymy, which is the assumption that women, but not men, experience gender-related persecution. Moreover, while the notion of women as political subjects is given little credence, it is also argued that the protection of women is dependent on their being viewed as victims of patriarchal cultures, and that the receiving states embrace postcolonial notions of 'modernity' while protecting women from 'traditional' and 'regressive' practices supported by other states [13-16]. While this refers to the asylum process as a whole, these aspects of gender (for exceptions, see [4] and [5]) and socioeconomic position are rarely considered in relation to credibility assessments; the possibility of similar processes as those described above are also excluded in relation to male applicants. Thus, the normative aspects of credibility, e.g. in relation to gender, are rarely addressed, and class is not elaborated on at all.

We argue that gendered and classed interpretations matter also in relation to male applicants, that men may in fact be situated at the other end of the spectrum of postcolonial notions of modernity, as non-victims, and that this is accentuated in relation to credibility assessments. By adopting a theoretical generalization drawn from the extensive body of literature on the fallacies that women encounter in the process, we wish to point out the continuity of this line of argumentation regarding gender and class in relation to male and female applicants. Drawing on constructionist theory and what Lipsky [17] has called the discretion of grassroot bureaucrats, our purpose is to analyse how narratives of gender and class are articulated, rendered meaningful, or silenced in credibility assessments. Two cases concerning male applicants are selected to illustrate these processes. We will begin by reviewing our theoretical framework, thereafter presenting our methodology, and lastly analysing our two selected cases.

\section{Credibility as a Social Construction}

"Credibility assessments are usually understood to involve checking for three things: internal consistency, external consistency (congruence with known facts), and plausibility" ([3], p. 700, emphasis added. Weston [18] is often credited with having identified these categories).

The dimensions of internal and external credibility are products of research and thus theoretical, while the concept of plausibility (in the form 'plausible') is incorporated into legal texts such as the UNHCR Handbooks. The process of evaluating external credibility focuses on whether the content of the applicant narrative is supported by available knowledge in the country information databases accessed by the investigating officer $[3,19]$. This includes the compatibility between people's 'subjective' descriptions of the threats they have experienced and the 'objective' safety situation as described in the databases. This act of comparison is based on a positivistic understanding, in which the applicant's narrative is checked against the relevant country information as if it were possible to put a blue print on the narrative to see if it fits the countryspecific pattern $[19,20]$.

However, credibility assessments tend to emphasize style of performance over content [5]. Here, the structure and shape of the narrative provided by the ap- 
plicant is of central importance $[3,19]$. The applicant is required to remember details such as the exact chronology of specific events, as well as the names of those present during the event. The dimension of internal credibility is related to this inner coherence and the richness or vagueness of detail as well as to consistency with the documentary evidence submitted in support of the claim. A story with few details and vague descriptions of people and places may easily be considered not credible. Thus, the ability to tell a good story that has support in the documentary evidence when relevant becomes an important part of the application process.

Plausibility could be described as step three in the process, when the other two aspects have been assessed. It is examined by asking the overall question 'is it likely that the claimed event has occurred?', thus serving as a basis for giving the applicant the benefit of the doubt even when all criteria for credibility are not met $[3,19]$. Depending on how plausibility is interpreted, it could serve as a concept that covers the 'subjective element' of the assessments [3,19]. However, because the concept is semi-legal and its meaning viewed as highly unclear [19], we will not use it. In addition to internal and external credibility, we wish to suggest the concept of social credibility. Thus we are arguing for a tripartite conceptual framework, not only focusing on internal and external factors, but also on the considerable influences of Western norms on factors such as race/ethnicity, gender, and class. The external dimension explicitly addresses whether the situation in the country described in the applicant narrative is consistent with the country-of-origin information. The internal dimension may also be involved in such an assessment. The social dimension addresses how administrators produce these arguments. Social credibility thus denotes the way in which different socio-cultural narratives are read [21] and is relevant in relation to assessments of both external and internal dimensions.

\footnotetext{
"When deciding which statements need to be proven, and when proof has been delivered; and when deciding which statements and which behaviour are considered credible, it is necessary to use certain normative standards. These standards are hard to make explicit, and most often they are not" ([4], p. 67).
}

\footnotetext{
"The refugee is most likely to be seen when she or he looks like 'us' or, when that is not possible, looks like what is being looked for" ([22], p. 197, emphasis in original).
}

Using 'knowledge' about phenomena-such as the situation in a country, the likelihood of a person performing or being subjected to certain actions-is thus not a neutral process, but includes the production of ideology $[23,24]$. The process of assessment therefore cannot be said to deal with the positive elucidation of facts, but rather to construe a specific version of reality that provides a space for acting on cultural norms. The 'subjective dimension' has been pointed out in research (e.g. $[3,25,26])$. For instance, Herlihy et al. [25] discuss the assumptions of the assessors. These approaches elucidate important aspects of the assessments, though these aspects are not analysed by focusing on how sociocultural narratives are read, as the present article intends to do. The narratives provided by the applicants are filled with details about social life and materiality. In reading these narratives as likely, we mean that the assessing officer needs to use cultural norms regarding gender, class, ethnicity/ race and other social factors required for orientation in professional life as well as in everyday life. Such 'narrative locations' are accounts that tell a story about how we position others and ourselves in relation to social categories, such as gender and class, at a specific point in time and space [23,27]. We argue that social credibility is of varying importance in different parts of the evaluation process.

\subsection{Postcolonial Discourse, Gender and Class}

According to Anthias [27], social division is constituted through a complex process of collective imaginings and embodied practices. Social regulations and other taxonomic devices in the social sphere serve as emergent features of social relations. Gender, ethnicity and class establish these divisions intersectionally. In his article 'The West and the Rest', Hall [28] describes the postcolonial division of the world in terms of discursive power. Mohanty [29] argues that Western feminist discourses based on the same premises have created a monolithic third world woman. We mean that use of these notions is an ever-present possibility in framing assessors' narratives and lines of argument on, for example, gender and class in relation to credibility [30], as when assumptions about 'modernity' and 'victimhood due to patriarchal cultures' come to play an important role in the assessment of female asylum seekers. Razack ([15], p. 72) characterizes this as 'fighting sexism with racism'.

In the assessments, case officers use 'known facts' about the political situation in the country of origin, as well as about the country's judicial system and position on the world political map (seen from a Western perspective). The social divisions created/employed in the assessments invest equally in such postcolonial notions and create certain, though varying, narratives around nation, gender and class. This, in turn, builds up assumptions about social credibility.

Following Butler [24], gender is primarily a politically and discursively informed category. Being gendered always entails certain claims on the subject. This means that the forces that cause women and men to become what they are consist of political and ideological articulations that are informed by-and that establishpower relations. Scott [31] shows how men are seen as genderless subjects in that they embody the invisible norm, but how they are nonetheless circumscribed 
by gendered scripts. In the asylum area, men are the taken-for-granted subjects, and as such, they are associated with the 'normal' political causes of asylum, while women are associated with 'gendered reasons' such as rape [11]. Likewise, classification along class lines begins with grouping individuals based on the criteria of competencies, property and knowledge, which are related to allocation of power, that is, to one's ability to influence one's environment and legitimacy in relation to political, cultural and representational levels [27]. This means that being categorized as 'woman' or 'man' along with certain class characteristics brings with it an assumed political affiliation in society, which creates certain narratives, granting access to rights and resources as well as duties and obligations. We argue that the notions of gender and class are made intelligible - and as such can be equally damaging — both when they are used and when they are silenced.

Related to the social dimension of credibility assessments are also 'victimhood' and a political dimension. As argued by Christie [32], the concept of victim is loaded with expectations regarding characteristics and behaviour. The ideal victim is an innocent old lady who causes no harm to others and is subjected to bodily abuse. In the asylum area, this ideal type would be equated with a man actively engaging in political deeds in public [10]. The political dimensions of a case are of great importance $[2,4,33]$. This is not made explicit in policy documents, but is still the norm by which the practice works: "the notion of the 'political refugee' dominates asylum practice and, as a consequence, the question of what is [viewed as] political is of primary importance" ([12], p. 45). We treat the notion of the 'political' as a discourse, which also seems to guide assessments of credibility.

We mean that social credibility not only contains expectations concerning the right kind of victimhoodmeaning that it is gendered, classed, and involves a political dimension-but also concerning 'known facts' about the meaning of these categories in the country of origin as well as about the country's political situation and position on the world political map. These dimensions cooperate in constructing the lines of argumentation in the credibility assessments; they also imply that the 'known facts' are produced through the discursive power of postcolonial reasoning.

\section{Method}

The asylum process in Sweden begins with registration at the Migration Board, which is followed by an oral hearing conducted by a case officer. Lawyers are assigned to applicants. A decision is ideally reached within six months (until 2010) and taken by the officer and a decision-maker. Negative decisions can be appealed to the Migration Court and thereafter to the Migration Court of Appeal, which function like ordinary administrative courts. In the Court, the Board becomes the counterpart to the applicant and his or her lawyer. The average acceptance rate of asylum applications in Sweden between $1990-2010$ is $53 \%$. Two percent are accepted as refugees, the majority through subsidiary protection.

The present article is based on the material of 100 anonymised case files from the Migration Board (not public), randomly selected from records for the months of March 2009 and March 2010. The files consist of an equal distribution of negative and positive decisions and of gender of applicant. Within this distribution, we have focused on the 50 files on male applicants. The files contain the lawyer's petition, the protocols from the hearing at the Board, the decision of the Board, and the verdicts from the Migration Court (public) if the applicant has appealed; this also describes the content of the two cases presented, which were both appealed. The lawyer's petition conveys the cause of the application as if it were a resume of what the applicant has told the lawyer. The protocols are written in question/answer form and produced by the officer during the hearing. The verdicts contain the history of the case, the claims of the parties and the ruling of the court. In the excerpts, the applicant is referred to as $A$, the lawyer as $L$, the Migration Board as MB, and the Migration Court as MC.

The two cases presented below have been selected to illustrate how the line of argumentation based on class and gender can be made in the case of male applicants. The argumentation made in the 50 case files shows the rudiments of, whole sections of or builds exclusively on credibility assessments related to social dimensions, depending on the nature of the case. The two cases presented build exclusively on credibility assessments (internally, externally and socially), while they also serve well as examples. What we call 'assessments of social credibility' are often referred to by the Board officers as 'common sense' evaluations, which seems to be the main instrument at hand. Theoretically this could be labelled discretion, stereotyping, or acting based on cultural norms/normative standards $[4,17,23]$.

We focus on situations in which class and gender seem to inform the arguments in the cases, a claim that is then established analytically. This means looking for reasoning and qualities that are silently active in the assessments, yet rarely made explicit in written text [4]. It is also important to remember that the applicants' narratives as mediated in the case files have undergone several transformations $[34,35]$. The interpreter [36], the case officer, and the applicant's lawyer are all (sometimes quite significant) 'transformative filters', through which different parts of the narratives become accentuated. Other transformative 'filters' are of course the applicant's experience of the situation, and his/her ability to understand the importance of mastering certain ways of narrating and constructing the story. Moreover, the narrative may change a great deal in the transformation from spoken to written 
language $[34,36]$. Finally we, as authors, emphasizing some aspects and not others have transformed the information once again. The notion that the files may hide as much as they reveal is a noteworthy finding per se, contradicting institutional assumptions that the files offer transparency and comprehensive information about the cases [37]. Research on case files can therefore be said to deal to a great extent with the non-written, implicit or tacit assumptions embedded in processes of assessment.

In the empirical section, the presentations of the two cases differ slightly. This depends partly on a certain lack of consistency in the cases, which in turn has spurred the retrieval of varying amounts of the information documented in the files.

\subsection{Narrative Analysis}

Narrative analysis focuses on how people create and use culturally connected narratives in their perception of the world $[21,27,38]$. "[T]alk is studied as an example of more general interpretative practices" ([38], p. 459). The analytical fundament is institutionalized speech that can be connected to culturally informed ways of understanding social life. This macro-level dimension of single speech acts contains information on categories such as country/nation, race/ethnicity, social class and gender [27]. Anthias uses the concept of 'narratives of location', which draws on the collective stories told around us, that is, from the discourses, representations and normative systems that are used to organize our experiences in terms of certain conventional norms or rules. In assessment of asylum applications, the language of law and bureaucracy shapes utterances [39], but these quite specific discourses do not exist in a vacuum. The discourse of law communicates with the norms and discourses of the society of which it is part. In this sense, the officers also use culturally prevalent understandings of what gender, class, terrorism, a politically active person or a victim or other social categories mean.

\section{Case Study I: Ravin. Class and Politics}

Ravin is a 35-year-old applicant from Afghanistan. The claims made by Ravin are turned down in the first instance, the Migration Board, and approved in the second instance, the Migration Court. The lawyer's petition, in which we find the first version of the narrative of Ravin, is quite detailed and articulate. According to the petition, Ravin earned his living as a butcher in Afghanistan; a certain incident forced him to leave his country. He and his friends sat in a park talking:

$\mathrm{L}$ : They discussed the situation in the country, suicide bombings...and the Afghan government. They also talked about Ravin's uncle, who previously worked for the national army, but was killed by the Taliban. A group of men overheard their discussion and started to mock Ravin's uncle and said he was not a martyr because he fought against the Taliban. The Taliban were martyred as they fought for Allah. ([40], petition, p. 5. All translations are made by the authors).

A fight started, but was interrupted when Ravin and his friends left the scene. Later Ravin was working at a wedding, preparing the meat, when suddenly someone called to him. He recognized the men from the park. The petition states that one of them called out:

L: 'That's the guy who is the Americans' slave.' Ravin answered that he neither took the Americans' nor the Taliban's party. They then called him a heretic and a non-believer, and abducted and abused him ([40], petition, p. 5).

There was a fight and Ravin fell to the ground; when about to rise again he grabbed his butcher's knife in self-defence. One assailant was killed, and another was cut. When Ravin managed to run away he heard the men shout: 'Get him, he killed [X]' ([40], p. 5). Ravin decided to hide. Instead of apprehending Ravin, the police arrested his father. The police were paid off and Ravin's father was released. Ravin's father later told him that the father of the man he had killed was very influential and powerful and had sworn to avenge the death of his son. Ravin was therefore advised to leave the country. The lawyer argues that Ravin can neither escape to another part of Afghanistan nor trust he will get a fair trial there. If he returns, he will be killed. In the decision, the Board summarizes the long, detailed story of Ravin/his lawyer as follows:

MB: The lawyer's petition and the oral briefing have revealed the following: Ravin was accused of sympathizing with the Americans and subjected to beatings and death threats. In self-defence Ravin killed a man named $[X]$. On return to Afghanistan Ravin risks being murdered by relatives of $[\mathrm{X}]$. No protection from the authorities is available ([40], decision, p. 2).

In their decision, the Board denies the external and internal credibility of Ravin's story due to the lack of official identity documents and the lack of details and verifiable information, such as names and facts. The story is also considered vague and lacking in details. The Board states:

MB: Ravin does not know the name of the powerful person in question, neither what group he belongs to nor which contacts he has with people in the government. The Board does not find it probable that the father of the man Ravin killed has any direct influence on the legal system in Afghanistan. The Board therefore finds it unlikely that Ravin, if he is threatened in the part of the country where he lives, cannot escape to another part of Afghanistan ([40], decision, p. 4).

The Board thus uses 'knowledge' about how power, 
influence and the legal system in Afghanistan work. This is a kind of argument that is hard to counter. Ravin's/his lawyer's answer in court seems to grasp what is possible to counteract, claiming that Ravin is not from the specific area where the incident took place, and therefore cannot name the person. The crucial point of the argument of the Board, though, is that the whole story told by Ravin is unlikely.

MB: [The area from which Ravin comes] is under the Afghan central power's control with the support of the Americans and not under the Taliban's rule. It is not likely that sons of the former employers would openly show support for the Taliban such as the deceased is said to have done. Neither is it likely that someone from such an influential family would seek a conflict with such an insignificant person as Ravin ([40], verdict, p. 7).

Here an argument based on the social dimension of credibility is posed. The Board doubts that people in this area would show strong and visible support for the Taliban, as the area is officially controlled by the Americans. Furthermore, it is not considered likely that such an important and powerful man would bother with picking a fight with such an 'insignificant' person as Ravin. "As such there are reasons to question the credibility of Ravin's story" ([40], p. 7). Instead the Board proposes internal migration as an available option.

In this case, the Court interprets the information in the case differently. Instead of vague and poor, the internal dimension is referred to as reliable and detailed, authentic and self-experienced. In this second round, additional information has been added to the case, such as the identities of the assailants, supporting the claim that they are indeed powerful and influential in Afghanistan, thus supporting both internal, external and social credibility. Ravin's relatives have also been threatened, beaten and forced to hide, which strengthens Ravin's claims to victimhood. The Court states that the story throughout the investigation has remained essentially unchanged, but with an increased level of detail and that the Board has not been able to demonstrate that Ravin has made contradictory statements. The Court, therefore, explicitly rejects the Board's arguments:

MC: The objection of the Board that [the deceased and the injured], who have been said to belong to families of higher social and economical status, would neither discuss nor pick a fight with a person from a lower social class has not been supported. It is further not unlikely that a conflict between people regarding support for the Taliban can take place, even if this particular area is under governmental control. On the contrary, the information given in this part of the application is not unlikely, and is not contradicted by what is known about the situation in Afghanistan. There are, therefore, no reasons for doubt ([40], verdict, p. 10).
The Court sees the external, internal and social dimensions of credibility as meeting their standards. Ravin will not be able to find a place safe from his persecutors in Afghanistan as long as the safety situation in the area in question is considered very insecure; furthermore the police force is considered corrupt and therefore Ravin, given his inferior class position, may not get a fair trial by the local authorities. The Court states that: 'in many cases representatives of the judiciary choose to refrain from legal action due to the political contacts, ethnic or clan affiliation of the perpetrator.' ([40], p. 11); being of low social standing and without such affiliations, Ravin will not be able to influence or pay off the judges in the same way as his rich and influential assailants can. As such, one can see how both the Board and the Court act on 'knowledge' and presumptions about the political and legal situation in Afghanistan, and on the meaning of class in this milieu, but draw on different narratives concerning these themes.

In the Board's assessment, Ravin's story fails in relation to internal and external credibility, but most importantly social credibility. Apart from not finding the consistency of the narrative satisfactory, the narrative is not thought to be in accordance with what are considered 'known facts' about social and political groups and the political climate in the region. They also do not find a suitable concept with which to categorize Ravin ([40], verdict, p. 8) possibly due to that they do not find 'class' to be meaningful as a legal concept. The concept 'social group' appears in the main paragraph of the Aliens Act; there is no evidence or prohibition against it functioning as a concept for social class [33]. Here it is not attributed to social class, although class is readily discussed in the case. Still 'class' and the political dimension serve equally to undermine the story and are important to their rejection of credibility.

Normative leakage is evident as when the Board draws on narratives of class, judging it unlikely that a man of high standing would bother with an unimportant person like Ravin. This is also evident concerning the argument that draws on the stability offered by the American troops. The Board doubts that there would be such open support for the Taliban in the presence of the American troops, and thus rejects the possibility of considering Ravin a victim. Through these moves, persons of low class are positioned as passing under the radar of political and class conflicts occurring on 'higher levels'. In this narrative, individuals of low class are deprived of (political) importance in relation to people of high standing in Afghanistan, as well as within the asylum system. In what way is this also a gendered narrative, or what interpretation would have been used if Ravin had been a woman? The silence on gender is evident here and in accordance with the arguments made by Scott [31].

The belief that a man of high standing would not bother with an unimportant man like Ravin might also 
explain why the Board does not present another possible interpretation, that Ravin's stabbing is a criminal act that would be tried in court. By rejecting the story as non-credible, Ravin is already positioned as a nonvictim and therefore the question of how to interpret events in the story becomes meaningless. This version is instead brought up by the Court in the appeal process, where the Court also draws on narratives of class in considering the judicial system in Afghanistan: even if Ravin has committed a crime, the Court believes that Ravin's opponent would influence the trial through the force of power and position.

Ravin alludes to his position as a victim of politicized violence by stating he was called 'the Americans' slave' by the Taliban persecutors. This allusion is implicitly used by the Board to strengthen doubts about the story, because they do not believe there is open support for the Taliban in the area. The Court, which does not doubt the story, turns the argument around and finds support for the Taliban in the area to be 'not unlikely' and thereby supports Ravin's claim to victimhood based on both class and politics. In the narrative the Court uses, American troops cannot provide absolute control, and it is not unlikely that people of low class would be targets in political conflicts on 'higher levels'. Ravin's lack of means and power on political and representational levels becomes key to regarding his story as credible and him as a victim.

The main component in the Court's interpretation of the story's credibility seems to be based on assumptions regarding class, social relations and political power. Contrary to the assessment of the Board, the narrative then reads that Ravin, due to his inferior status and position, is a 'natural' target for powerful people with political connections in society. Political narratives about the Taliban and the Americans are broadly adopted in the West [41], especially since 9/11 2001. In the face of this larger narrative of global politics, the Migration authorities come to act in a divided world in terms of both class and political power struggles. The 'lower classed position' can be divided into either being a victim who is given a role in social and political relations (poor with no power and a political target) or as insignificant (poor and therefore of interest to no one).

As we can see, class and the political dimension play an important role in the credibility assessments made in the case. Moreover, credibility assessments based on narratives of class and world politics can be used for different purposes, such as to negate or sustain claims.

\section{Case Study II: Aras. Gender and Class}

Aras is a 33-year-old applicant from the Kurdish part of Iraq. The case has produced a number of arguments and counterarguments made by the Court and the Board as well as Aras and his lawyer. Aras did not get approval in any of the instances. The lawyer's petition is detailed, but less eloquent than in the case of Ravin.
The same applies to Aras' speech referred to in the protocol. According to the information in the case, Aras' life had been threatened, which made him decide to leave the country.

A: I was a chauffeur for a representative within the PUK [Patriotic Union of Kurdistan]. I followed him everywhere. I had contact with his family, and his daughter...We had a relationship in secrecy for a long time. At last I went to her father to ask for her hand... He said that I was his chauffeur and that it would be inappropriate for me to marry her. We continued our relationship and she got pregnant. One day she followed her mother to the doctor...it showed that she was pregnant...she then sent me a message that we had been caught...I left for Baghdad. The father...and other relatives killed her to show it wasn't accepted according to Islam... They came to my family and said...that my family should kill me or that her family should kill me...He had a lot of power the girl's father. He pressured my family and my brother got fired. They demanded that I should turn myself in ([42], protocol, p. 6).

In the protocol, Aras claims that after the girl had been murdered, her body was dumped in a public place to serve as an example. The father of the girl hired people to find him in Baghdad and threats were made to his relatives. Aras' mother contacted the police for protection:

A: They blamed us and said that her son should be murdered too. They had no power to influence that person, it is according to Islam. They rule. The government can't do anything, women get killed for the sake of honour. The number of dead in May 2008 was 20 women...in the Kurdish area. The persecutors are free. The crime was that two people fell in love ([42], protocol, p. 7).

L: Aras says he is very afraid of the girl's family and especially her father who is influential in all of Iraq. When his mother made a complaint to the police, it appeared that they could not do anything about it because of the girl's father's position of power...The man who threatens him is part of the PUK, and has been at war with the president of Iraq and has had close links with him. The man is in charge of a staff of pershmerga [Kurdish 'guerilla'] ([42], verdict, pp. 2-3).

When the persecutors found out where Aras was hiding, he fled the country. The Board and the Court deny the credibility of Aras' narrative on several counts, both internal and external. The Board is not even convinced he was in Iraq at the time in question. It finds the story weak, vague, unclear, and lacking in consistency. The Court finds the story vague, but not inconsistent. Hence the internal credibility of the narrative is dismissed, which is likely to influence other aspects of the credibility assessment as well, as could be seen in the Board's claims in the case of Ravin. 
There are also questions concerning the story's social credibility. On the subject of gender, the Board argues that personnel expeditions to Iraq have shown that mediation by the police in honour-related cases is possible. The Board and the Court wonder why this has not been tried in this case. According to the decision, Aras comments on this as follows:

\begin{abstract}
A: Komalayati [mediation] could work in some cases when the families involved are very poor, in [this] case the father is very strong and nothing could stop him from taking vengeance. Mediation in [this] case would be that Aras would be turned in to the father so that he could take revenge and thereby restore his honour ([42], decision, p. 8).
\end{abstract}

Both at the Board and in Court, Aras/his lawyer repeatedly bring up the power and influence of his perpetrator as well as his own inferior position, an argument that is not met by the authorities. Instead they discuss gender in honour-related cases and question the role of men as victims in such cases.

MB: In the event a man becomes a target of honourrelated threats, these usually come from his own family or relatives ([42], verdict, p. 6).

MC: In available country information reports, it can be read that it is mostly women who are affected by honour-related violence. In the event men are drawn into the conflicts, it is mainly to restore their own family name [and thereof as perpetratorsnot victims] ([42], verdict, p. 9).

Aras contests the position of perpetrator. In court he/his lawyer explain that men are not as severely affected as women in honour-related crimes because the men are often cautioned and thus can escape. He insists on being a victim and that, apart from his mother and brother, his whole family have disowned him because of what happened and that he must therefore also hide from his own relatives. This last argument coincides with that of the Board, above.

Dismissal of the credibility of Aras' story in both instances is made with reference to internal and external dimensions that mutually reinforce each other. Doubts about Aras even being in Iraq at the time are supported by assessment of internal credibility (vagueness and lack of detail) and social credibility (the gendered claims of Aras do not correspond to 'known facts'). This is possibly why a plausible Convention ground, which in this case would be 'gender', is not discussed either. Doubts about social credibility are used in both instances by addressing gender in honour-related cases, while the class issue brought forward by Aras is ignored. If the class issue had been accorded importance, it might have nuanced the 'knowledge' that the police in Iraq mediate in honourrelated conflicts.

The Board and the Court discuss honour-related violence as a 'known fact' and circumstance. To connect this to a larger narrative of honour-related violence, the debate in the research in Sweden, on the one hand, establishes honour-related violence as encompassing phenomena that show very fixed and strongly gendered positions [43,44]. The honour of the family is kept through the chastity of the women. Men, it is said, are given more space and freedom to act and are mainly affected by the honour system as potential perpetrators of transgressions. On the other hand, the very fixed roles ascribed in relation to honour-related violence are negated and the harm associated with using such firm models is discussed and criticized $[45,46]$. One of the problems associated with using such a fixed model can be illustrated by the claims made in the case of Aras and as such show the normative leakage in the assessment. The argumentation of the Board and the Court follows the model connected to the former argument using a highly specific narrative on gender. This 'knowledge' is used to dismiss the complexity found in the area of violence, gender and power (and the possibility of protection). Aras is not openly said to be discredited because he is a man involved in an honour crime, but it is claimed to be unlikely that, as a man, he would be a victim in this case.

Aras' counter-narrative brings forth another gendered and classed story, in which men can be victims of honour-related violence and in which lack of power is enhanced by his own and his perpetrator's class position. In this narrative, he is threatened and told by the police authority that he is culpable on the basis of both class and gender. The Migration authorities foreclose the perspective of a man being a victim based on a gendered narrative, and the issue of class is met with silence. Gender is used here as an instrument to dismiss credibility, while claims of class are overlooked, also resulting in the denial of credibility.

\section{Conclusions: Credibility, Postcolonial Discourse, Gender and Class}

By analysing two selected cases, we have given examples of and shown how class and gender can influence credibility assessments in relation to male applicants. If it is fairly obvious in the assessments when expectations of internal credibility-narratives of weak consistency, structure and logic-are not met, then it is much more difficult to discern when expectations concerning the social factors of class and gender have an impact on the assessments. What we call social credibility is not acknowledged in the process; still it seems essential in claims made with respect to credibility. It can therefore be said that the Migration authorities lack a method for reflection in accordance with notions of class and gender. The structure and content of an applicant's story are, of course, intimately linked to his or her material and social living conditions. Therefore, class and gender can be expected to play a central role in constructing a certain position. It 
is not equally certain that this information will be treated in a conscious or transparent way in the readings of the authorities. The metaphor 'normative leakage' aims to capture how class and gender norms as well as postcolonial reasoning implicitly become a part of the assessments. We therefore wish to call for a more reflexive approach to what we call social credibility.

Narratives of gender and class, and how these are activated, may undermine or sustain the claims of the applicants based on 'known facts' and the cultural beliefs and normative standards of the assessors. This involves being assigned the right kind of victimhood in accordance with gender, class and the political dimension. Normative leakage influence this process of (de)victimization. Without the political and classed aspects, Ravin is just a killer, and without the risk of honour crimes, Aras is merely an adulterer. In both cases, the readiness to recognize class relations and gendered expectations serves to (de)victimize them. This runs parallel to similar processes in assessments of asylum-seeking women.

Our main conclusion is that while normative standards based on gender and class in light of postcolonial reasoning affect women negatively or limit their ability to pass as victims of anything other than patriarchal structures/cultures [14], equivalent-though opposite -processes can be seen in relation to male applicants. The Western feminist discourse [29], thus, favours treating women as victims of capitalist and patriarchal structures, but does not find them credible in relation to political narratives. Men, in contrast, tend to be positioned as perpetrators and non-victims of patriarchal structures and pass under the radar of class structures. This puts the credibility of their claims to victimhood in such settings to the test. Protection in the name of the Western feminist discourse as such is carried out at the expense of protection of women as political subjects and at the expense of protection of men-who are constructed as women's counterpartsas non-political subjects $[14,29]$. Moreover, in the case of Ravin, the silence on gender [31] can be read

\section{References}

1. Swedish Alien Act. Stockholm, Sweden: Fritzes; 2005.

2. Noll G, editor. Proof, Evidentiary Assessment and Credibility in Asylum Procedures. Leiden, The Netherlands, and Boston, MA, USA: Martinus Nijhoff Publishers; 2005.

3. Sweeney JA. Credibility, Proof and Refugee law. International Journal of Refugee Law. 2009;21(4):700 -726 .

4. Spijkerboer T. Stereotyping and Acceleration: Gender, Procedural Acceleration and Marginalised Judicial Review. In: Noll G, editor. Proof, Evidentiary Assessment and Credibility in Asylum Procedures. as being due to the fact that his narrative does not depart from the model of gendered behaviour. While in the case of Aras, gender is discussed because he does not follow the model of gendered behaviour. Male and female applicants would benefit equally from acknowledging these processes, as the normative standards are mutually dependent [24,29]. Victimization should be viewed as a process; it is not either a political act carried out by a single subject (as is expected in cases concerning men) or an oppressive situation that may victimize the subject (as is expected in cases concerning women), but consists of both these elements and is independent of gender.

Previous research has rarely emphasized the normative aspects of credibility assessments within asylum practice as being gendered and classed. What we call social credibility could also serve as a starting point for attending to the use of norms and, as such, as an important element of the internal/external dimensions. We believe that awareness of the way in which these dimensions and categories work can help make credibility assessments more just and secure-and thus ethical in that they pay attention to normative leakage. The concept of gender is adopted in the Alien Act in Sweden. Regarding the concept of 'social group' there is no prohibition against it functioning as a concept for social class. While use of these concepts functions poorly in relation to the asylum legislation, they are not even developed in relation to credibility assessments, which are at the core of the practice of assessing asylum applications. Paying attention to these processes means dealing with one of the most basic forms of social inclusion in Western societies [47].

\section{Acknowledgements}

The project, of which the article is part, is funded by the Swedish Research Council (no. 2009-1939). We wish to thank five anonymous reviewers, and participants at the credibility seminars at the departments of Sociology, Social Work and IPKL at the University of Gothenburg, for comments on earlier drafts of this paper.

Leiden, The Netherlands, and Boston, MA, USA: Martinus Nijhoff Publishers; 2005. pp. 67-102.

5. McKinnon S. Citizenship and the Performance of Credibility: Audiencing Gender-Based Asylum Seekers in U.S. Immigration Courts. Text and Performance Quarterly. 2009;29(3):205-221.

6. Noll G. Asylum Claims and the Translation of Culture into Politics. Texas International Law Journal. 2006;41(3):491-501.

7. Baines E. Vulnerable Bodies: Gender, the UN and the Global Refugee Crisis. New York, NY, USA: Ashgate; 2004.

8. Bexelius M. Asylrätt, kön och politik: En handbok för jämställdhet och kvinnans rättigheter. Stockholm, Sweden: Rådgivningsbyrån för asylsökande 
och flyktingar; 2008.

9. UNHCR. Handbook for the Protection of Women and Girls. Geneva, Switzerland: UNHCR; 2008.

10. Bhabha J. Embodied Rights: Gender Persecution, State Sovereignty, and Refugees. Public Culture. 1996; 9(1):3-32.

11. Anker D. Refugee Status and Violence against Women in the Domestic Sphere: The Non-State Actor Question. Georgetown Immigration Journal. 2001;15 (3):391-402.

12. Spijkerboer T. Gender and Refugee Status. London, UK: Ashgate; 2000.

13. McKinnon S. The Discursive Formation of Gender in Women's Gendered Claims to U.S. Asylum. Tucson, AZ, USA: Arizona State University; 2008.

14. Oxford CG. Protectors and victims in the gender regime of asylum. National Women's Studies Association Journal. 2005;17(3):18-38.

15. Razack SH. Domestic Violence as Gender Persecution: Policing the Borders of Nation, Race, and Gender. Canadian Journal of Women \& Law. 1995;8 (2):45-88.

16. Razack SH. The 'Sharia Law Debate' in Ontario: The Modernity/Premodernity Distinction in Legal Efforts to Protect Women from Culture. Feminist Legal Studies. 2007;15(3):3-32.

17. Lipsky M. Street-Level Bureaucracy. New York, NY, USA: Sage; 1980.

18. Weston A. A Witness of Truth: Credibility Findings in Asylum Appeals. Immigration and Nationality Law and Practice. 1998;12(3):87-89.

19. UNHCR. Beyond Proof. Credibility Assessment in EU Asylum Systems. Brussels, Belgium: UNHCR; 2013.

20. Flärd $\mathrm{H}$. The Use, Misuse and Non-Use of Country of Origin Information in the Swedish Asylum Process. Stockholm, Sweden: The Swedish Refugee Advice Centre; 2007.

21. Somers M. The Narrative Constitution of Identity: A Relational and Network Approach. Theory and Society. 1994;23(5):605-649.

22. Berg L, Millbank J. Constructing the Personal Narratives of Lesbian, Gay and Bisexual Asylum Claimants. Journal of Refugee Studies. 2009;22(2): 195-223.

23. Foucault M. The Archaeology of Knowledge. London, UK: Routledge; 1989.

24. Butler J. Gender Trouble. New York, NY, USA: Routledge; 1990.

25. Herlihy J, Gleeson K, Turner S. What Assumptions about Human Behaviour Underlie Asylum Judgements? International Journal of Refugee Law. 2010;22(3):351-366.

26. Millbank J. The Ring of Truth. A Case Study of Credibility Assessment in Particular Social Group Refugee Determinations. International Journal of Refugee Law. 2009;21(1):1-33.

27. Anthias F. Social Stratification and Social Inequality: Models of Intersectionality and Identity. In: Devine $F$, Savage $M$, Scott J, Crompton R, editors.
Rethinking Class. Culture, Identities \& Lifestyle. Basingstoke, UK: Palgrave MacMillan; 2005. pp. 24-45.

28. Hall S. The West and the Rest: Discourse and Power. In: Hall S, Held D, Hubert D, Thompson K, editors. Modernity: An Introduction to Modern Societies. Cambridge, UK: Polity Press; 1992. pp. 184-227.

29. Mohanty TC. Feminism without Borders. Decolonizing Theory, Practicing Solidarity. London, UK: Duke University Press; 2003.

30. Musarrat Akram S. Orientalism revisited in asylum and refugee claims. International Journal of Refugee Law. 2000;12(1):7-40.

31. Scott JW. Gender and the politics of history. New York, NY, USA, and Chichester, UK: Colombia University Press; 1999.

32. Christie N. The ideal Victim. In: Fattah $A E$, editor. From Crime Policy to Victim Policy-Reorienting the Justice System. Hampshire/London, UK: Macmillan Press; 1986. pp. 17-30.

33. Wikrén G, Sandesjö H. Utlänningslagen med kommentarer. Stockholm, Sweden: Norstedts; 2010.

34. Mishler E. Representing Discourse: The Rhetoric of Transcription. Journal of Narrative and Life History. 1991;1(4):255-280.

35. Blommaert J. Investigating Narrative Inequality: African Asylum Seekers' Stories in Belgium. Discourse \& Society. 2001;12(4):413-449.

36. Gómez Díez I. The Role of the Interpreter in Constructing Asylum Seeker's Credibility. A Hearing at the Spanish Asylum and Refugee Office. Sociolinguistic Studies. 2010;4(2):333-370.

37. Diesen C. Bevis och prövning av migrationsärenden. Stockholm, Sweden: Norstedts; 2007.

38. Talja S. Analyzing Qualitative Interview Data: The Discourse Analytic Method. Library and Information Science Research. 1999;12(4):459-477.

39. Heger Boyle E, Busse E. Institutional Vulnerability and Opportunity: Immigration and America's 'War on Terror'. Law \& Social Inquiry. 2006;31(4):947-974.

40. Case 57A.

41. Abiri E. The Securisation of Migration. Towards an Understanding of Migration Policy Changes in the 1990's-The Case of Sweden. Gothenburg, Sweden: Gothenburg University; 2000.

42. Case 11A.

43. Schlytter A. Rätten att själv få välja. Lund, Sweden: Studentlitteratur; 2004.

44. Wikan U. En fråga om heder. Stockholm, Sweden: Ordfront förlag; 2004.

45. Carbin M. Mellan tystnad och tal: Flickor och hedersvåld i svensk offentlig politik. Stockholm, Sweden: Stockholms Universitet; 2010.

46. Wikström H. Den problematiska invandrarfamiljen: Kunskapsbildning om hedersrelaterat våld. In: Bergman $H$, Eriksson $M$, Klinth $R$, editors. Föräldraskapets politik. Stockholm, Sweden: Dialogos förlag; 2011. pp. 173-196.

47. Hedetoft UR. Social Inclusion: Inaugural Editorial. Social Inclusion. 2013;1(1):1-2. 